\title{
Wpływ spękań ciosowych na ksztaltowanie przebiegu dolin rzecznych zachodniego Podhala
}

\author{
Influence of joints on the formation of river valley in the Western Podhale
}

\author{
Karol Majewski \\ Instytut Geografii, Uniwersytet Pedagogiczny,Kraków,kmajewsk@up.krakow.pl
}

Zarys treści: $\mathrm{W}$ artykule przedstawiono wyniki badań nad zgodnością kierunkowości spękań ciosowych, pomierzonych w odsłonięciach skalnych w korytach potoków, z kierunkami przebiegu dolin rzecznych niższego rzędu. Analizy wskazują, że górne odcinki badanych dolin kierunkowo nawiązują do orientacji dominującego systemu spękań ciosowych. Zgodność ta może stanowić świadectwo procesu formowania się dolin rzecznych wzdłuż spękań ciosowych systemu diagonalnego. W przeciwieństwie do górnych odcinków badanych dolin, w ich dolnych odcinkach przebieg osi doliny jest w większości przypadków niezgodny z przebiegiem kierunków spękań ciosowych systemu diagonalnego. W świetle przeprowadzonych badań należy stwierdzić, że kierunek przebiegu analizowanych dolin mógł ulec zmianie w toku ich rozwoju, szczególnie w okresie zlodowaceń tatrzańskich, gdy dolne odcinki dolin były wypełniane materiałem fluwioglacjalnym.

Słowa kluczowe: spękania ciosowe, doliny rzeczne, Podhale, Polskie Karpaty Wewnętrzne

Abstract: The directions of joints, measured in bedrock outcrops in stream channels, have been compared with the directions of the low-order valleys. The results indicate that upper courses of all studied valleys are consistent with the orientation of dominant joint system. This correlation can be an evidence of valley-forming process along joints of diagonal system. In contrast to the upper courses, lower courses of most of the valleys are inconsistent with diagonal joint system. According to the research results, the valley directions changed in the course of their development, especially during the Tatra glaciations, when lower courses of the valleys were filled with fluvio-glacial material.

Key words: tectonic joints, valley, Podhale region, Polish Central Carpathians

\begin{abstract}
Wstęp
Dotychczas dowodem na tektoniczne uwarunkowania rozwoju dolin rzecznych była analiza zgodności ich prostolinijnych odcinków z rozpoznanymi w terenie uskokami lub lineamentami wyznaczonymi na podstawie analizy zdjęć satelitarnych albo cyfrowego modelu wysokościowego (DEM) (Graniczny 1989, Ostaficzuk 2003, Badura, Przybylski 2005, Zuchiewicz 2010). Zdecydowanie rzadziej w badaniach morfostrukturalnych zwraca się uwagę na zgodność kierunkowości sieci rzecznej z orientacją spękań ciosowych (Maruszczak 1972, Zuchiewicz 1987). Dotychczas brakuje szczegółowych badań na temat znaczenia spękań ciosowych w predysponowaniu przebiegu
\end{abstract}

dolin rzecznych, mimo że spękania takie należą do najpowszechniej występujących nieciągłości tektonicznych odsłaniających się w skalistych odcinkach koryt rzecznych.

W niniejszym opracowaniu przedstawiono wyniki badań zależności między orientacją spękań ciosowych a biegiem dolin rzecznych zachodniego Podhala. Badania te zmierzały do określenia roli spękań ciosowych w założeniach i ewolucji form dolinnych, w tym również we współczesnym odmładzaniu ich rzeźby.

Obszar Podhala jest predestynowany do tego typu badań morfostrukturalnych z kilku względów. W korytach potoków odsłonięcia spękanych skał są bardzo liczne, jest też wiele publikacji dotyczących spękań ciosowych 
fliszu podhalańskiego (Halicki 1963, Pokorski 1965, Boretti-Onyszkiewicz 1968a, b, Morawski 1973, Mastella, Mizerski 1977, Domonik 2003, Ludwiniak 2008). Nie brakuje również opracowań o wpływie tektoniki na rzeźbę tego terenu (Baumgart-Kotarba 1978, 1984, 1991, Kukulak 1988, 1991b).

\section{Charakterystyka obszaru badań}

Obszarem badań morfostrukturalnych były doliny potoków: Domagalskiego, Chrobaków, Garczkowskiego i Greków, będących lewymi dopływami Czarnego Dunajca w zachodniej części Pogórza Gubałowskiego (ryc. 1).

Badane doliny powstały w utworach fliszu podhalańskiego: dolina Potoku Domagalskiego w większości w warstwach chochołowskich dolnych, tylko jej początkowy odcinek i cała długość trzech pozostałych dolin - w warstwach chochołowskich górnych (Gołąb 1954, Watycha 1977). Na planie tektonicznym synklinorium podhalańskiego teren badań jest w większości usytuowany w obrębie jego strefy osiowej. Jedynie dolny odcinek doliny Potoku Domagalskiego leży na północnym skrzydle synklinorium, a górny odcinek Potoku Greków - na jego skrzydle południowym (Mastella, Mizerski 1977, Mastella $\mathrm{i}$ in. 1988). Położenie warstw skalnych nie jest jednakowe we wszystkich analizowanych dolinach. W dolinach potoków Domagalskiego oraz Chrobaków wartości azymutów upadu koncentrują się szczególnie w przedziale wartości $130-210^{\circ}$, co wskazuje na zapadanie warstw w kierunku południowym. W przypadku doliny Potoku Garczkowskiego biegi warstw wyznaczają kierunek SW-NE, przy czym w górnym odcinku doliny przeważają upady w kierunku NW, natomiast w dolnym - w kierunku SE. Warstwy fliszu podhalańskiego w dolinie Potoku Greków zapadają z kolei przede wszystkim ku północny i północnemu wschodowi, o czym świadczą wartości azymutów upadu zawarte głównie w przedziale wartości 330-80 . Wartość upadu warstw skalnych we wszystkich analizowanych dolinach z reguły nie przekracza $20^{\circ}$ (Watycha 1976).

Badane doliny mają dna rozcięte głębokimi (3-8 m) wciosami, w których potoki mają na przeważającej długości skalne koryta. W tych miejscach na wychodniach skalnych odsłaniają się spękania ciosowe będące powierzchniami nieciągłości, wzdłuż których nie doszło do przemieszczenia rozspojonych części, tworzące uporządkowane geometrycznie zbiory spękań seryjnych (Dadlez, Jaroszewski, 1994). Na obszarze zachodniego Podhala wyróżnia się pięć zespołów ciosu w zależności od orientacji spękań względem rozciągłości synklinorium podhalańskiego (zob. Boretti-Onyszkiewicz 1968a,b, Ludwiniak 2008). Najliczniej występują tutaj spękania należące do dwóch zespołów ukośnych zwanych również diagonalnymi $\left(\mathrm{D}_{\mathrm{L}}\right.$ oraz $\left.\mathrm{D}_{\mathrm{R}}\right)$, dla których azymuty spękań zawierają się $\mathrm{w}$ przedziałach $143-173^{\circ}$ dla zespołu $\mathrm{D}_{\mathrm{R}}$

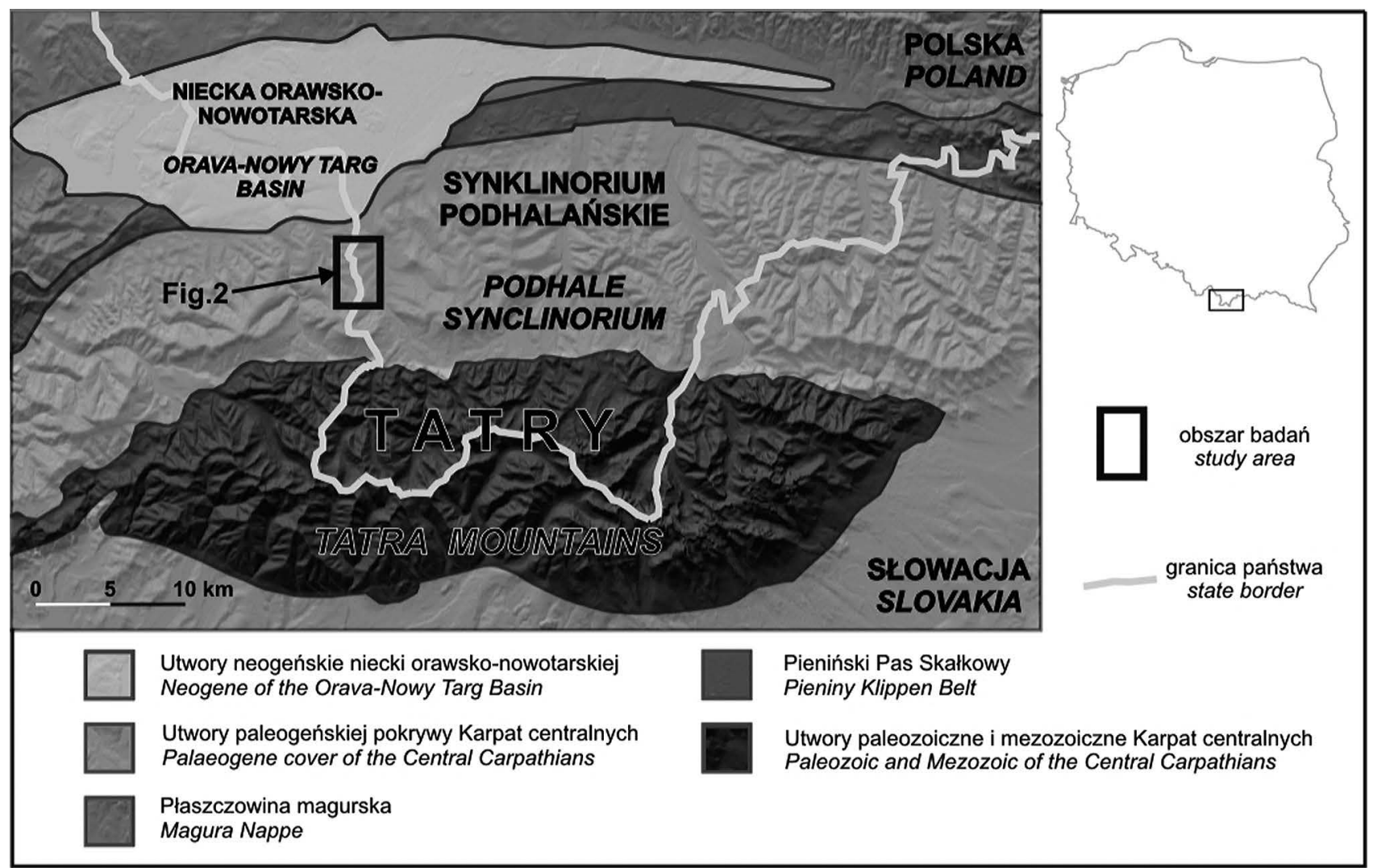

Ryc. 1. Lokalizacja terenu badań na tle budowy geologicznej północnej części zachodnich Karpat centralnych (wg Mastelii i in. 2012, zmienione)

Fig. 1. Study area and geology of northern part of the Central Western Carpathians (after Mastella et al. 2012, modified) 
oraz $13-58^{\circ}$ dla zespołu $D_{L}$ (Ludwiniak 2008). Kolejne dwa zespoły spękań ciosowych we fliszu Podhala to zespół podłużny (L) i subpodłużny (L'), w przypadku których azymuty spękań przyjmują wartości odpowiednio $65-103^{\circ}$ oraz $48-78^{\circ}$ (Ludwiniak 2008). Azymuty spękań należących do ostatniego wyróżnianego zespołu ciosu zwanego zespołem poprzecznym (T) reprezentują wartości w przedziale od $175^{\circ}$ do $25^{\circ}$ (Ludwiniak 2008).

Występowanie elementów rzeźby Podhala uwarunkowanych strukturą podłoża podkreślano już wielokrotnie. Wskazywano, że związki z młodą tektoniką mają m.in.: zaburzone wysokości cokołów skalnych teras rzek podhalańskich (Baumgart-Kotarba 1978) czy też schodowy układ poziomów grzbietowych (Baumgart-Kotarba 1984, Kukulak 1991b). Przebieg niektórych odcinków dolin rzecznych (m.in. Czarnego Dunajca, potoków Cichego, Bystrego, Skrzypnego) wiązany był również z występowaniem stref uskokowych (Ozimkowski 1992). Wskazywano ponadto na tektoniczne założenia form osuwiskowych, w tym m.in. na zgodność elementów linijnych osuwisk (skarpy główne, skarpy boczne, rowy rozpadlinowe) $\mathrm{z}$ orientacją zarówno uskoków, jak i spękań ciosowych (Kukulak 1988).

\section{Metody badań}

Pomiarów orientacji płaszczyzn spękań ciosowych dokonano w 39 odsłonięciach piaskowców fliszowych w korytach badanych potoków. Łącznie wykonano 804 pomiary biegu płaszczyzn tych spękań. Dla każdej z analizowanych dolin utworzono w programie GEOrient po 3 diagramy rozetowe orientacji ciosu, przypisane odcinkom koryt wydzielonym ze względu na rozkład odsłonięć mierzonych spękań ciosowych lub lokalne zmiany orientacji spękań. W celu określenia orientacji biegu osi badanych dolin dokonano wektoryzacji osi tych dolin z map topograficznych w skali 1:10 000 w oprogramowaniu GIS. Wektoryzację przeprowadzono w oparciu o 50-metrowe odcinki całej długości doliny, dla których w tabeli atrybu- tów zapisany został ich azymut. Dane z tabeli atrybutów wyeksportowano do programu GEOrient i na ich podstawie utworzono diagramy rozetowe przebiegu analizowanych osi dolin. Analogicznie, wykorzystując dodatkowo ortofotomapę z witryny Geoportal.gov.pl, dokonano wektoryzacji biegu wądołów i innych form erozji linijnej na zboczach dolin. Pomiary parametrów morfometrycznych badanych dolin wykonano w oprogramowaniu GIS, używając map topograficznych w skali 1:10 000 i DEM. Za granicę odmłodzenia rzeźby dna badanych dolin przyjęto miejsce występowania najwyżej położonego progu skalnego w ich korytach.

\section{Przebieg kierunków spękań ciosowych na wychodniach fliszu w badanych korytach}

W badanych wciosach zdecydowanie przeważają spękania należące do zespołów $\mathrm{D}_{\mathrm{L}}$ oraz $\mathrm{D}_{\mathrm{R}}$ tworzących system diagonalny ciosu, przy czym spękania zespołu $D_{L}$ są liczniejsze aniżeli $\mathrm{D}_{\mathrm{R}}$. Dominujące azymuty kierunków spękań zawierają się $\mathrm{w}$ przedziale $35-50^{\circ}$ dla zespołu $\mathrm{D}_{\mathrm{L}}$ oraz $140-165^{\circ}$ dla zespołu $\mathrm{D}_{\mathrm{R}}$ (tab. 1, ryc. 2). W dwóch dolinach na krótkich ich odcinkach występują jednak odstępstwa od dominujących na całym badanym obszarze kierunków spękań. W dolnym odcinku koryta Potoku Domagalskiego azymuty spękań koncentrują się w przedziałach $60-100^{\circ}$ oraz $0-10^{\circ}$, natomiast w środkowym - dominujące azymuty mieszczą się w przedziałach 90-100 i $10-20^{\circ}$. Orientacja ciosu na tych odcinkach oraz pewne cechy charakterystyczne, takie jak krzywoliniowość czy też nierówność ich powierzchni, pozwalają zaliczyć je do zespołów ciosu: podłużnego (L) dla azymutów $60-100^{\circ}$ i poprzecznego (T) dla wartości $0-20^{\circ}$ (Mastella, Mizerski 1977, Ludwiniak 2008). Podobnie jest w środkowym odcinku koryta Potoku Garczkowskiego, gdzie na krótkim dystansie spękania koncentrują się w przedziałach $10-20^{\circ}$ oraz $80-90^{\circ}$. W pozostałych odcinkach koryt tych dwóch potoków oraz we wszystkich

Tabela 1. Wyniki pomiaru przebiegu kierunków spękań ciosowych na badanym obszarze

Table 1. Results of the measurements of joint directions in the study area

\begin{tabular}{|c|c|c|c|c|}
\hline Doliny potoków & Odcinek skalny & $\begin{array}{c}\text { Liczba pomierzo- } \\
\text { nych azymutów } \\
\text { spękań }\end{array}$ & $\begin{array}{c}\text { Dominująca orientacja spękań } \\
\text { (przedział z największą liczbą } \\
\text { wystąpień kierunków) }\left(^{\circ}\right)\end{array}$ & $\begin{array}{c}\text { Mediana azymutu spękań } \\
\text { w najliczniejszym przedziale }\left(^{\circ}\right)\end{array}$ \\
\hline \multirow{3}{*}{ Domagalski } & górny & 54 & $30-40$ & 35 \\
\hline & środkowy & 32 & $90-100$ & 97 \\
\hline & dolny & 73 & $70-80$ & 76 \\
\hline \multirow{3}{*}{ Chrobaków } & górny & 52 & $40-50$ & 47 \\
\hline & środkowy & 45 & $320-330$ & 324 \\
\hline & dolny & 41 & $40-50$ & 45 \\
\hline \multirow{3}{*}{ Garczkowski } & górny & 104 & $30-40$ & 39 \\
\hline & środkowy & 63 & $10-20$ & 15 \\
\hline & dolny & 85 & $40-50$ & 44 \\
\hline \multirow{3}{*}{ Greków } & górny & 93 & $40-50$ & 46 \\
\hline & środkowy & 90 & $40-50$ & 44 \\
\hline & dolny & 72 & $40-50$ & 42 \\
\hline
\end{tabular}




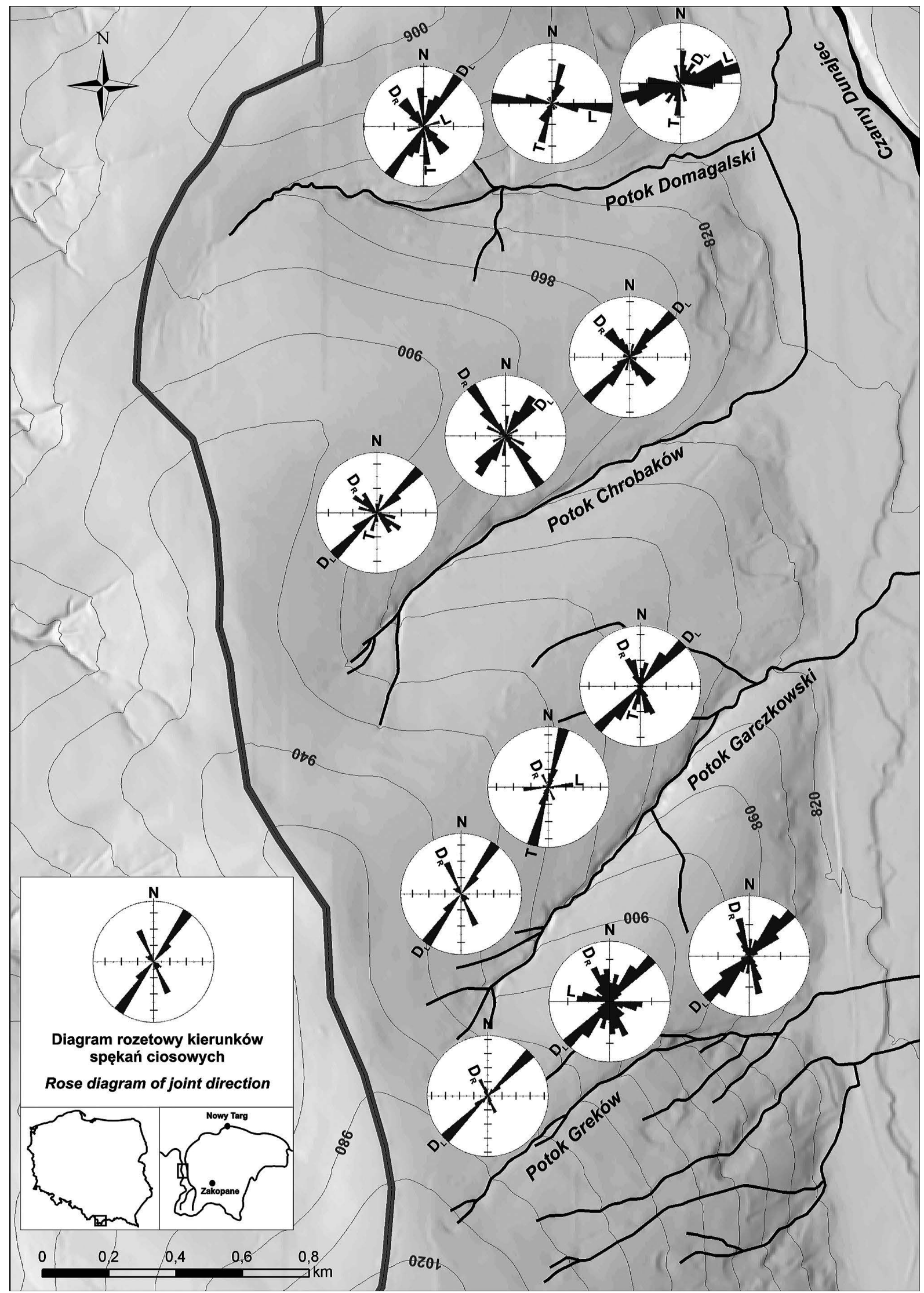

Ryc. 2. Przebieg kierunków spękań ciosowych na badanym obszarze. Główna jednostka na osiach diagramów odpowiada 10-procentowemu udziałowi określonego kierunku w analizowanej grupie pomiarów. Kierunki spękań na utworzonych diagramach zostały pogrupowane w przedziały o rozpiętości $10^{\circ}$

Fig. 2. Directions of joints in the study area. The main scale interval on diagram axis represents $10 \%$ share of specific direction within analyzed group of measurements. Directions of joints on diagrams are grouped in $10^{\circ}$ intervals 
odsłonięciach skalnych w korytach potoków Chrobaków i Greków zdecydowanie dominują spękania systemu diagonalnego. Pomimo że w górnych odcinkach badanych dolin brak odsłonięć skalnych, należy przypuszczać, że również na tych obszarach dominują spękania systemu diagonalnego, zwłaszcza że we wszystkich badanych dolinach w odsłonięciach skalnych usytuowanych najbliżej terenów źródliskowych zdecydowanie przeważają spękania zespołu $D_{L}$. System ciosu diagonalnego jest też zgodny $\mathrm{z}$ orientacją uskoków skośnych na Podhalu. Uskoki te wykorzystują bowiem istniejące płaszczyzny ciosowe systemu diagonalnego lub są równoległe do nich (Pokorski 1965, Boretti-Onyszkiewicz 1968a). Na badanym obszarze udokumentowano m.in. przebieg normalnego uskoku Krowiarek, który przecina dolinę Potoku Domagalskiego, a którego przebieg nawiązuje właśnie do orientacji spękań zespołu $\mathrm{D}_{\mathrm{L}}$. Nie można także wykluczyć, że inne strefy dyslokacyjne towarzyszą badanym dolinom, zwłaszcza że w licznych opracowaniach wyznaczano na tym terenie lub w jego najbliższym sąsiedztwie przebieg przypuszczalnych uskoków i lineamentów tektonicznych (Ozimkowski 1992, Wasiluk 2009), w tym m.in. lineamentu myjawskiego (Bac-Moszaszwili 1993).

\section{Kierunkowa orientacja przebiegu badanych dolin}

Średnie wartości biegu badanych dolin wyraźnie różnią się od siebie. Najbardziej prostolinijny przebieg ma dolina Potoku Garczkowskiego (tab. 2, ryc. 3). W pozostałych dolinach zaznacza się natomiast wyraźna zmiana kierunku przebiegu szczególnie pomiędzy jej odcinkiem górnym a dolnym. Jest jednak charakterystyczne, że kierunki przebiegu osi wszystkich analizowanych dolin w ich górnych przebiegach są bardzo zbliżone. Pomierzone azymuty osi początkowych odcinków dolin (w przypadku Potoku Garczkowskiego na całej długości doliny) zawierają się w przedziale $30-55^{\circ}$, a ich średnie wartości wahają się w granicach od $40,1^{\circ}$ dla Potoku Chrobaków do $48,1^{\circ}$ dla Potoku Greków. Osie dolin potoków Domagalskiego, Garczkowskiego i Greków w swych dolnych odcinkach odchylają się w kierunku wschodnim, przy czym odchylenie to jest nierówne w poszczególnych do- linach. Najmocniej swój bieg zmienia dolina Potoku Domagalskiego, dla której średni azymut w dolnym odcinku wzrasta do $85^{\circ}$. W przypadku dolin potoków Chrobaków i Greków odchylenie od początkowego biegu jest mniejsze, a średni azymut biegu doliny w ich dolnych odcinkach wynosi odpowiednio: $60,7^{\circ}$ i 79,6 $6^{\circ}$.

\section{Ewolucja rzeźby badanych dolin w czwartorzędzie}

Początki wcinania się rzek w inicjalną powierzchnię Pogórza Gubałowskiego wiąże się z okresem górnoplioceńskim bądź wczesnoplejstoceńskim (Klimaszewski 1952, Baumgart-Kotarba 1984). Na taki wiek badanych dolin wskazuje też charakter rzeźby w ich początkowych odcinkach, nie ulegających odmłodzeniu wtórnymi wciosami. Formy dolinne są tutaj bowiem łagodnymi i szerokimi nieckami o dnach wyścielonych miąższymi pokrywami zwietrzelinowymi i z niewyraźnymi granicami między dnem a zboczami. Cechy te mogą dowodzić, że na tym obszarze zachodziły żywotne procesy soliflukcyjne, typowe dla chłodniejszych okresów plejstocenu.

Szczególnie istotne zmiany w rozwoju badanych dolin nastąpiły w okresie zlodowaceń tatrzańskich. Charakter i natężenie procesów rzeźbotwórczych w analizowanych dolinach ściśle nawiązywały w tym czasie do przebiegu procesów morfologicznych zachodzących w dolinie Czarnego Dunajca na przedpolu Tatr. W okresach glacjalnych niższe odcinki badanych dolin były zasypywane materiałem fluwioglacjalnym, natomiast $\mathrm{w}$ interglacjałach $\mathrm{i}$ interstadiałach dochodziło $\mathrm{w}$ nich do usuwania zdeponowanych osadów wodnolodowcowych i intensywnego rozcinania den dolinnych (Halicki 1930, Klimaszewski 1952).

Najwyższy poziom zasypania doliny Czarnego Dunajca i jej bocznych dolin można wiązać z glacjałem mindel, kiedy Dunajec wypływał już z Tatr przełomem witowskim ku północy (Halicki 1930). Nie ma jednak pewności, czy nie nastąpiło to wcześniej - w okresie zlodowacenia günz, kiedy to przy wylocie Orawicy i Czarnego Dunajca do Kotliny Orawskiej formowała się najstarsza pokrywa żwirowa: suchohorska i domajska (Romer 1929, 1930, Halicki 1930, Klimaszewski 1988, Baumgart-Ko-

Tabela 2. Wyniki pomiaru azymutów przebiegu osi badanych dolin

Table 2. Results of the measurements of the valley axis azimuth

\begin{tabular}{|c|c|c|c|c|}
\hline Doliny potoków & Odcinek doliny & $\begin{array}{l}\text { Dominujące wartości azy- } \\
\text { mutu biegu osi doliny }\left(^{\circ}\right)\end{array}$ & $\begin{array}{c}\text { Średnia wartość azymutu } \\
\text { biegu osi doliny }\left({ }^{\circ}\right)\end{array}$ & $\begin{array}{c}\text { Mediana azymutu biegu os } \\
\text { doliny }\left({ }^{\circ}\right)\end{array}$ \\
\hline \multirow{2}{*}{ Domagalski } & górny & $30-50$ & 44 & 44 \\
\hline & dolny & $60-110$ & 85 & 85 \\
\hline \multirow{2}{*}{ Chrobaków } & górny & $30-50$ & 40 & 40 \\
\hline & dolny & $40-70$ & 61 & 62 \\
\hline Garczkowski & cała dolina & $30-50$ & 41 & 41 \\
\hline \multirow{2}{*}{ Greków } & górny & $40-60$ & 48 & 48 \\
\hline & dolny & $70-90$ & 80 & 78 \\
\hline
\end{tabular}




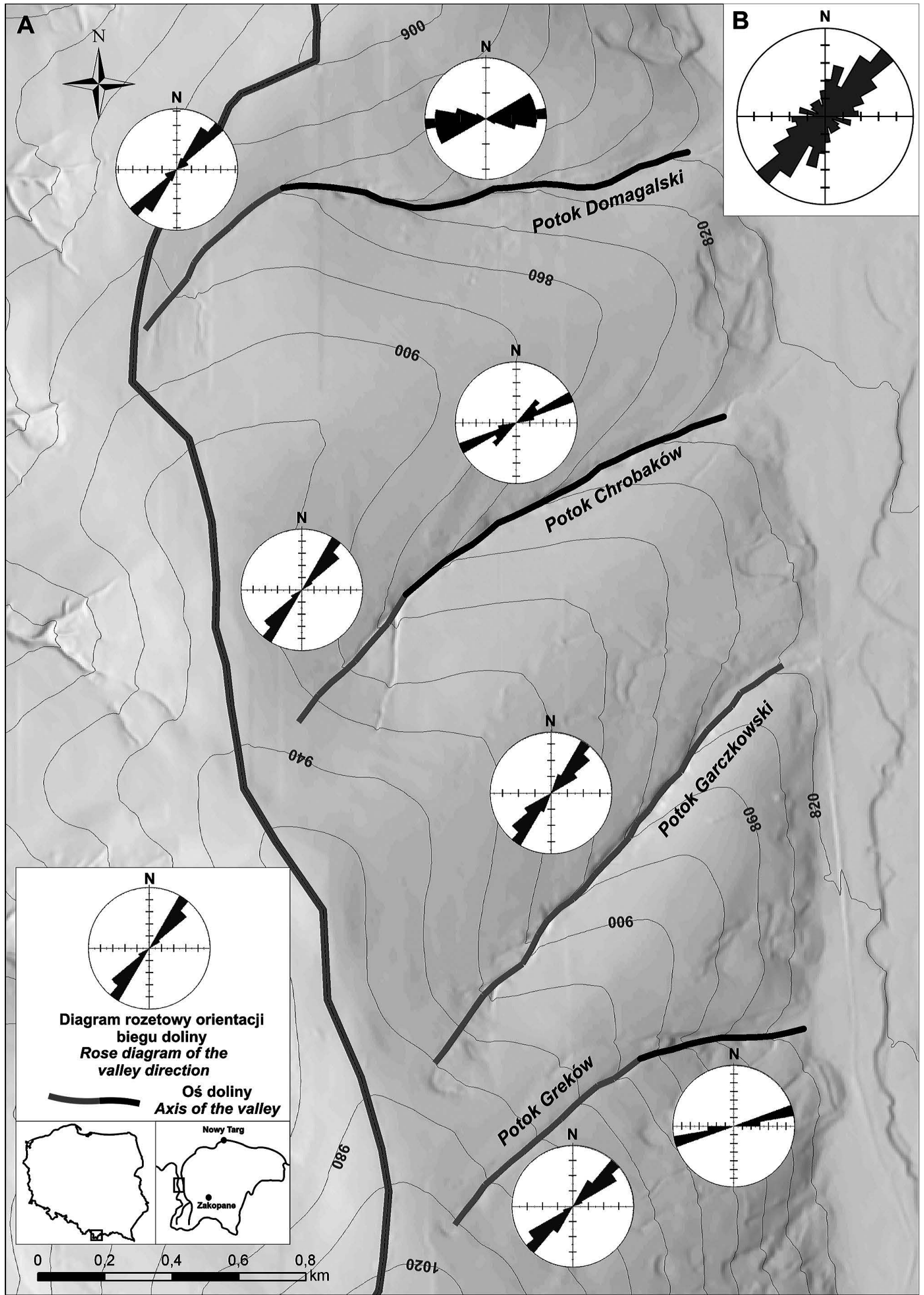

Ryc. 3. A - bieg dolin na badanym obszarze; główna jednostka na osiach diagramów odpowiada 10-procentowemu udziałowi określonego kierunku w analizowanej grupie pomiarów; B - diagram rozetowy orientacji wądołów i debrzy na zboczach analizowanych dolin; pojedyncza jednostka na osi diagramu odpowiada 5-procentowemu udziałowi określonego kierunku w analizowanej grupie pomiarów

Fig. 3. A - Valley directions in the study area. The main scale interval on diagram axis represents $10 \%$ share of specific direction within analyzed group of measurements; B - Rose diagram of gullies (with boggy bottom) and ravines on slopes of the studied valleys. A single scale interval on diagram axis represents $5 \%$ share of specific direction within analyzed group of measurements 
Tabela 3. Wybrane parametry morfometryczne badanych dolin

Table 3. Selected morphometric parameters of the studied valleys

\begin{tabular}{lcccc}
\hline \multicolumn{1}{c}{ Doliny potoków } & Długość doliny $(\mathrm{m})$ & Powierzchnia zlewni $\left(\mathrm{km}^{2}\right)$ & $\begin{array}{c}\text { Średni spadek profilu } \\
\text { podłużnego doliny (\%o) }\end{array}$ & $\begin{array}{c}\text { Udział odcinka } \\
\text { odmłodzonego w całej } \\
\text { długości doliny (\%) }\end{array}$ \\
\hline Domagalski & 2505 & 1,44 & 46 & 58 \\
Chrobaków & 2475 & 1,53 & 59 & 79 \\
Garczkowski & 2320 & 1,22 & 71 & 82 \\
Greków & 1775 & 0,46 & 110 & 72 \\
\hline
\end{tabular}

tarba 1991). Do dziś resztki ówcześnie zdeponowanych osadów zachowały się w dolinie Potoku Domagalskiego w formie luźnych otoczaków skał tatrzańskich. Najwyżej położone ich stanowisko znajduje się na wysokości $855 \mathrm{~m}$ n.p.m., a więc około $70 \mathrm{~m}$ nad współczesnym dnem doliny Czarnego Dunajca (Kukulak 1991a). Położenie tych osadów nawiązuje hipsometrycznie do miejsca wyraźnej zmiany biegu doliny Potoku Domagalskiego na kierunek W-E. Nie można wykluczyć, że to właśnie wówczas w obrębie luźnych osadów fluwioglacjalnych nastąpiła zmiana kierunku płynięcia wód Potoku Domagalskiego na kierunek odbiegający znacznie od jej wcześniejszego przebiegu (z SW-NE na W-E). Istotny również wydaje się fakt, że w dolinach potoków Chrobaków i Greków wyraźna zmiana kierunku ich biegu jest na podobnej wysokości względnej (odpowiednio na 80 i $85 \mathrm{~m}$ ) w stosunku do dna doliny Czarnego Dunajca. Pomimo braku w tych dolinach pokryw akumulacyjnych $\mathrm{z}$ tego okresu można wnioskować, że miejsce zmiany kierunku ich biegu może pośrednio świadczyć o wysokości zasypania tych dolin w tym czasie. Dodatkowo wysokości te ściśle nawiązują do wystąpień żwirów tatrzańskich z okresu najstarszych zlodowaceń Tatr w najbliższej okolicy badanego obszaru, m.in. na stokach Magury Orawskiej, Ostrysza i Kotelnicy, gdzie ich górną granicę odnotowywano właśnie na wysokości 70-80 m nad współczesnym dnem doliny Czarnego Dunajca (Halicki 1930).

Pozostałością tatrzańskich żwirów deponowanych w dolinach rzecznych podczas kolejnych zlodowaceń (mindel, riss) są jedynie ich resztkowe pokrywy występujące w dolnych odcinkach dolin potoków Domagalskiego i Chrobaków. Rozcięcie badanych dolin w trakcie interglacjału poprzedzającego ostatnie zlodowacenie sięgnęło prawdopodobnie do poziomu najwyższej terasy występującej dziś wzdłuż tych dolin (Kukulak 1991a). W starszym stadiale ostatniego zlodowacenia (würm I) ujściowe odcinki badanych dolin zostały ponownie wypełnione materiałem wodno-lodowcowym, ale w kolejnym interstadiale zostały one uprzątnięte wraz z osadami z wcześniejszych glacjałów. W młodszym stadiale ostatniego zlodowacenia (würm II) uformowana została pokrywa żwirowa ostatniej terasy plejstoceńskiej (3-6 m). Wyraźne nasilenie procesów erozyjnych miało miejsce u schyłku plejstocenu lub w starszym holocenie. To zapewne wówczas nastąpiło rozcięcie den wszystkich dolin głębokimi wciosami i usypanie u ich wylotów rozległych stożków napływowych. W holocenie miały miejsce jeszcze młodsze fazy akumulacji i erozji, których śladem jest obecność niskich teras akumulacyjnych w odcinkach wy- lotowych badanych dolin (Kukulak 1991a). Współcześnie intensywne procesy erozji wgłębnej i wstecznej zachodzą w środkowych odcinkach badanych dolin, prowadząc do dalszego odmładzania ich rzeźby.

\section{Odmłodzenie rzeźby badanych dolin}

Rozcinanie den badanych dolin, które mogłoby świadczyć o odmładzaniu preglacjalnej rzeźby w kolejnych interglacjałach i interstadiałach, w żadnej z analizowanych dolin nie sięgnęło obszarów źródliskowych. W ich górnych odcinkach zachowały się do dnia dzisiejszego miąższe pokrywy zwietrzelinowe świadczące o braku odmłodzenia w tych miejscach rzeźby dolinnej ukształtowanej we wczesnym plejstocenie.

Badane doliny różnicuje jednak nierówny stopień odmłodzenia ich rzeźby wyrażony udziałem odcinka rozciętego wciosem w długości całej doliny liczonym wzdłuż jej osi. Doliną odmłodzoną najsłabiej jest dolina Potoku Domagalskiego, natomiast procesy erozyjne najbardziej odmłodziły rzeźbę doliny Potoku Garczkowskiego (tab. 3). Niewielkie odmłodzenie rzeźby doliny Potoku Domagalskiego w porównaniu z pozostałymi badanymi dolinami wynika prawdopodobnie $\mathrm{z}$ najmniejszego średniego spadku profilu podłużnego potoku w tej dolinie. W kolejnych dwóch dolinach (potoków: Chrobaków i Garczkowskim), usytuowanych bardziej na południe, wraz ze wzrostem ich średniego spadku profilu podłużnego zwiększa się również stopień odmłodzenia rzeźby. Z kolei dolina Potoku Greków, cechująca się największą wartością spadku profilu podłużnego, została odmłodzona w mniejszym stopniu aniżeli doliny potoków Chrobaków i Garczkowskiego. Należy jednak zwrócić uwagę na wielkość powierzchni zlewni Potoku Greków, która zdecydowanie ustępuje powierzchniom zlewni wymienionych wyżej potoków. Mała powierzchnia zlewni tego potoku, pomimo dużego spadku podłużnego jego koryta, nie sprzyja szybkiemu odmładzaniu rzeźby doliny. Wpływ odporności skał na zróżnicowanie odmłodzenia badanych dolin wydaje się mało istotny. Świadczy o tym m.in. przykład doliny Potoku Domagalskiego, która na przeważającej długości rozcina warstwy chochołowskie dolne. Warstwy te $\mathrm{z}$ racji mniejszego udziału kompleksów piaskowcowych (Gołąb 1954) ustępują jednak pod względem odporności na procesy denudacyjne warstwom chochołowskim górnym. W warstwach chochołowskich górnych zostały wycięte pozostałe doliny, które pomimo odporniejszego podłoża mają rzeźbę bardziej odmłodzoną. 


\section{Znaczenie ciosu w ksztaltowaniu przebiegu dolin}

Przebieg górnych odcinków analizowanych dolin wyraźnie nawiązuje do dominujących na badanym obszarze kierunków spękań zespołu $\mathrm{D}_{\mathrm{L}}$. Zbieżność ta z pewnością nie jest przypadkowa. Analizowane doliny zostały prawdopodobnie uformowane wzdłuż płaszczyzn ciosowych zespołu $\mathrm{D}_{\mathrm{L}}$. Ukierunkowaniu i koncentracji przepływu wody wzdłuż tych płaszczyzn z pewnością sprzyjał charakter spękań systemu diagonalnego. Spękania te w porównaniu z pozostałymi zespołami ciosu, które występują na Podhalu, wyróżniają się bowiem zdecydowanie większą prostolinijnością oraz długością, a ich powierzchnie są gładsze, bardziej płaskie (Mastella, Mizerski 1977, Ludwiniak 2008). Wszystkie te cechy, a obok nich również kierunkowa orientacja ciosu zespołu $\mathrm{D}_{\mathrm{L}}$ - pośrednia w stosunku do nachylenia inicjalnej powierzchni Pogórza $(\mathrm{ku} N)$ i zboczy doliny Czarnego Dunajca (ku E), sprzyjały intensyfikacji procesów erozyjnych wzdłuż spękań. Konsekwencją tych procesów było z kolei wykształcenie form dolinnych o przebiegu zgodnym $\mathrm{z}$ orientacją dominujących na tym terenie spękań ciosowych. Nie można też wykluczyć, że kształtowanie przebiegu analizowanych dolin wzdłuż spękań ciosowych mogło być pochodną obecności nierozpoznanych jak do tej pory dyslokacji tektonicznych, którym spękania ciosowe naturalnie towarzyszą. Sugeruje to m.in. występowanie linijnych stref podmokłości w górnych odcinkach badanych dolin, zwłaszcza Potoku Domagalskiego, nawiązujących kierunkowo do rozciągłości lineamentu myjawskiego (Bac-Moszaszwili 1993, Baumgart-Kotarba 1996).

W trakcie ewolucji badanych dolin w czwartorzędzie przebieg dolnych odcinków dolin potoków Domagalskiego, Chrobaków i Greków uległ wyraźnym zmianom. W świetle przeprowadzonych badań wydaje się, że największy wpływ na zmianę kierunku ich biegu wywarło zasypanie owych dolin materiałem fluwioglacjalnym najprawdopodobniej w trakcie najstarszych zlodowaceń Tatr (günz, mindel). W obrębie luźnych osadów fluwioglacjalnych wody potoków mogły zmienić kierunek spływu na odbiegający od głównych kierunków tektonicznych. Kierunek ten odziedziczyły również formy dolinne rozwijające się najintensywniej w interglacjałach lub interstadiałach w wyniku natężenia procesów erozyjnych. Przypadek doliny Potoku Garczkowskiego, której przebieg na całej swej długości jest mniej więcej jednakowy, może świadczyć o lokalnej zbieżności przepływu wód w obrębie pokrywy wodnolodowcowej w czasie pierwszego zlodowacenia z przebiegiem preglacjalnej doliny.

$\mathrm{O}$ roli spękań ciosowych w rozwoju form dolinnych może pośrednio świadczyć także różny stopień odmłodzenia rzeźby analizowanych dolin. Warto zwrócić uwagę, że dolinę Potoku Garczkowskiego, odznaczającą się największym stopniem odmłodzenia, na całej jej długości cechuje zgodność przebiegu z orientacją spękań zespołu $\mathrm{D}_{\mathrm{L}}$. W pozostałych dolinach, w ich odmłodzonych odcinkach, zgodność ta nie jest już tak widoczna. W dodatku w dolinie Potoku Domagalskiego (najsłabiej odmłodzonej) w jej dolnym odcinku dominują inne zespoły ciosu, o cechach w mniejszym stopniu sprzyjających intensyfikacji procesów erozji wstecznej i wgłębnej. Tym samym stosunek przebiegu doliny względem orientacji spękań ciosowych wydaje się mieć (obok innych czynników wymienionych wcześniej) istotny wpływ na modyfikowanie natężenia procesów erozyjnych.

\section{Współczesne dowiązywanie biegu koryta do sieci spękań ciosowych $w$ analizowanych dolinach}

We wszystkich analizowanych dolinach, w ich odcinkach odmłodzonych wciosami, zaznacza się współcześnie W wielu miejscach zgodność przebiegu skalnego koryta $\mathrm{z}$ orientacją spękań ciosowych w podłożu (ryc. 4). Zjawisko to dobrze widoczne jest zwłaszcza w dolnych odcinkach dolin potoków Greków i Chrobaków, w których przebieg samej osi doliny nie nawiązuje do występujących w dnie koryta spękań. Odcinki te odznaczają się jednak dużą zmiennością przebiegu koryta w obrębie dna doliny. W wielu miejscach przebieg owych 10-50-metrowych fragmentów koryta ściśle nawiązuje do dominujących spękań ciosowych zespołu $\mathrm{D}_{\mathrm{L}}$. Obserwuje się poszerzone spękania i wąskie rynny erozyjne uformowane podczas wezbrań potoków. Formy te szczególnie dobrze widoczne są na odcinkach, gdzie spadek podłużny koryta pokrywa się z kierunkiem i wartością upadu warstw skalnych.

Do sieci spękań ciosowych oprócz koryt rzecznych swoim przebiegiem dowiązują się także liczne formy erozji linijnej na zboczach analizowanych dolin, w tym przede wszystkim wądoły. Sieć wądołów rozwinęła się głównie w nieodmłodzonych zamknięciach badanych dolin. Przebieg wądołów oraz innych form erozji linijnej na stokach na znacznej długości przeważnie nawiązuje do orientacji spękań zespołu $\mathrm{D}_{\mathrm{L}}$ (ryc. 5).

\section{Wnioski}

Wyniki badań wskazują, że spękania ciosowe mogą odgrywać istotną rolę $\mathrm{w}$ kształtowaniu przebiegu procesów erozyjnych zarówno w obrębie stoków, jak i w już ukształtowanych korytach rzecznych. Nieciągłości te W naturalny sposób predysponują przebieg form dolinnych w inicjalnym stadium ich rozwoju. Wzajemny stosunek przebiegu form dolinnych lub korytowych do systemu spękań na dalszym etapie ewolucji dolin rzecznych może z kolei w znaczący sposób wpływać na efektywność działania procesów erozyjnych i tempo odmładzania rzeźby dolinnej.

Doliny na analizowanym obszarze zostały ukształtowane wzdłuż spękań ciosowych zespołu diagonalnego. Zmiana biegu większości badanych dolin w ich dolnych odcinkach jest natomiast następstwem zasypania ich 


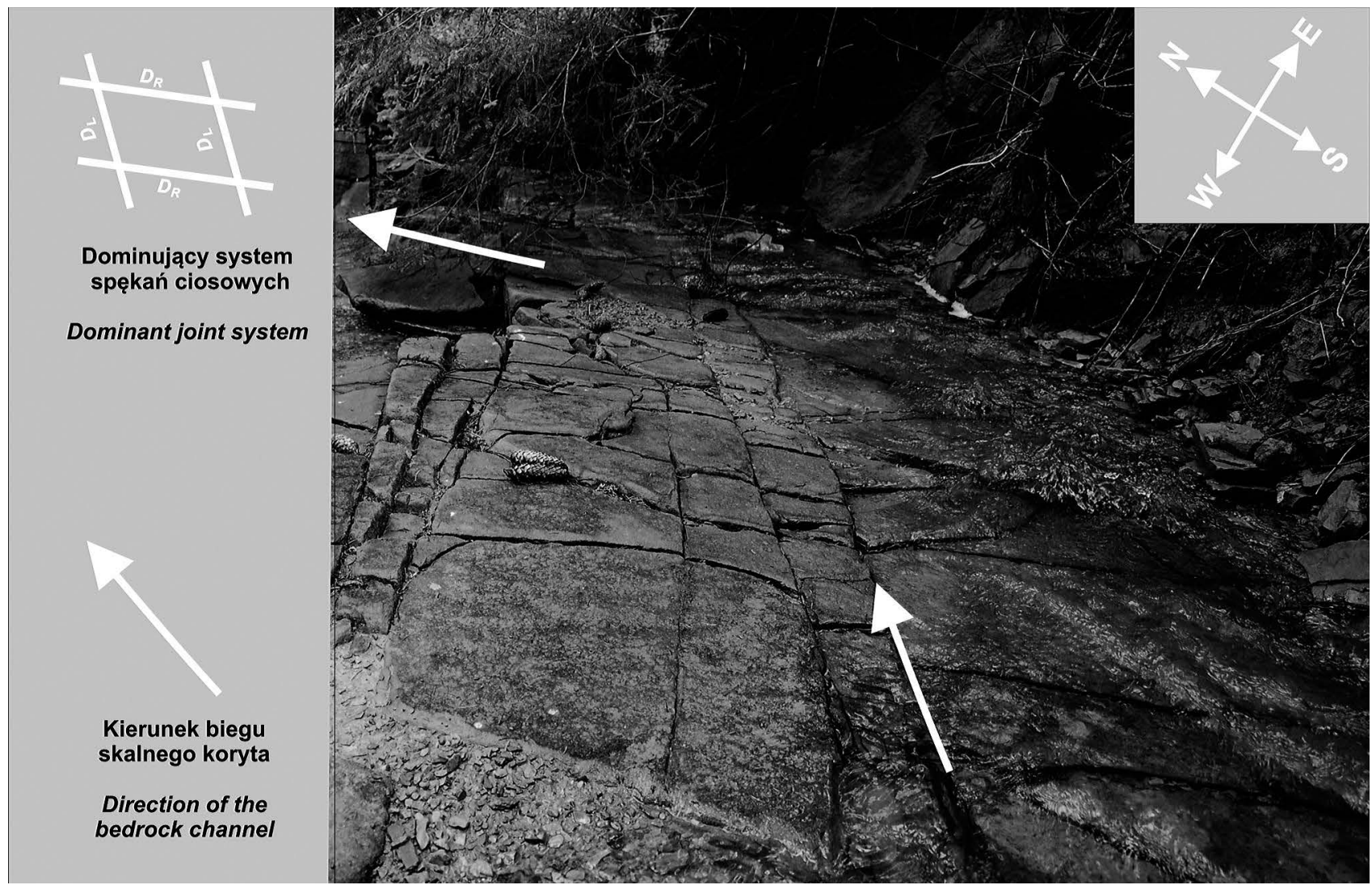

Ryc. 4. Kierunki biegu skalnego koryta i spękań ciosowych w Potoku Garczkowskim

Fig. 4. Directions of bedrock channel and joints in Garczkowski stream

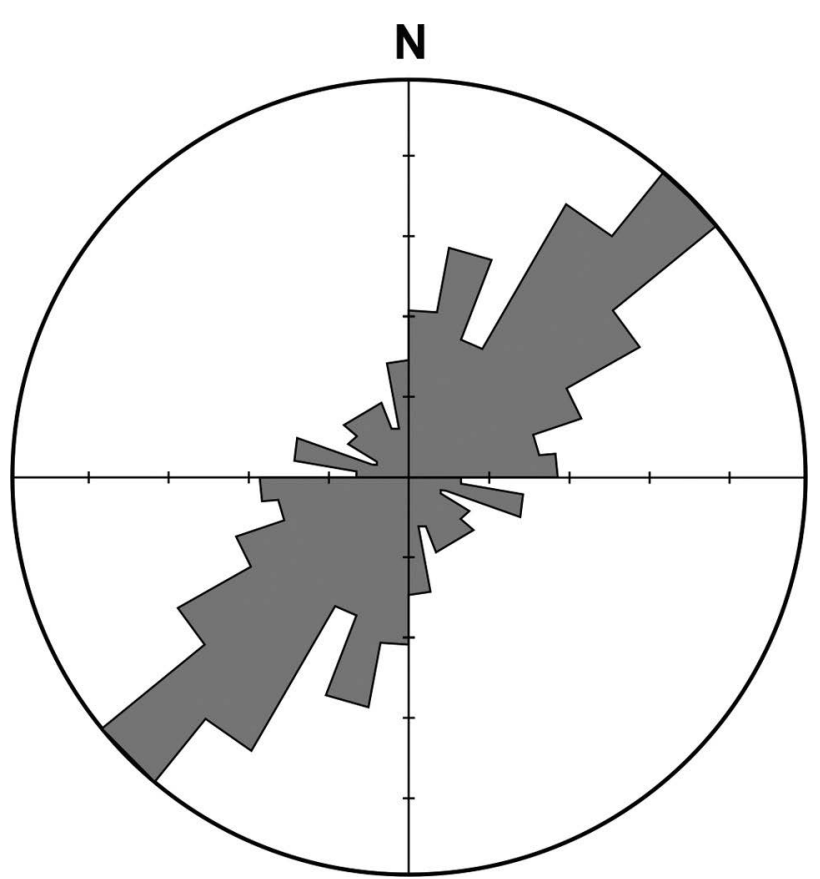

Ryc. 5. Diagram rozetowy orientacji wądołów i debrzy na zboczach analizowanych dolin. Pojedyncza jednostka na osi diagramu odpowiada 5-procenowemu udziałowi określonego kierunku w analizowanej grupie pomiarów.

Fig. 5. Rose diagram of gullies (with boggy bottom) and ravines on slopes of the studied valleys. A single scale interval on diagram axis represent $5 \%$ share of specific direction within analyzed group of measurements materiałem fluwioglacjalnym w czasie zlodowaceń tatrzańskich. Stopień zgodności przebiegu badanych dolin z kierunkowością spękań ciosowych zespołu $D_{L}$ ściśle koresponduje ze skalą odmłodzenia ich rzeźby. Współcześnie widoczne jest dowiązywanie się krótkich fragmentów koryt do głównych kierunków spękań ciosowych reprezentujących system diagonalny.

\section{Podziękowania}

Autor dziękuje dwóm anonimowym recenzentom za bardzo wnikliwą analizę artykułu oraz cenne komentarze i udoskonalenia pierwotnego manuskryptu.

\section{Literatura}

Bac-Moszaszwili M., 1993. Struktura zachodniego zakończenia masywu tatrzańskiego. Annales Societatis Geologorum Poloniae 63: 167-193.

Badura J., Przybylski B., 2005. Application of digital elevations models to geological and geomorphological studies - some examples. Przegląd Geologiczny 53: 977-983.

Baumgart-Kotarba M., 1978. Zróżnicowanie ruchów tektonicznych w świetle analizy czwartorzędowych teras doliny Białki Tatrzańskiej. Studia Geomorphologica Carpatho-Balcanica 12: 95-112.

Baumgart-Kotarba M., 1984. Kształtowanie koryt i teras rzecznych w warunkach zróżnicowanych ruchów tektonicznych (na przykładzie wschodniego Podhala). Prace Geograficzne IGiPZ PAN 145: 1-133.

Baumgart-Kotarba M., 1991. Rozwój geomorfologiczny Kotliny Orawskiej w warunkach ruchów neotektonicznych. Studia Geomorphologica Carpatho-Balcanica 25-26: 3-28. 
Baumgart-Kotarba M., 1996. On origin and age of the Orava Basin, Western Carpathians. Studia Geomorphologica Carpatho-Balcanica 30: 101-116.

Boretti-Onyszkiewicz W., 1968a. Anizotropia ciosowa piaskowców fliszowych Podhala zachodniego w świetle badań wytrzymałościowych. Biuletyn Geologiczny Uniwersytetu Warszawskiego 10: 115-152.

Boretti-Onyszkiewicz W., 1968b. Cios we fliszu zachodniego Podhala. Acta Geologica Polonica 18: 101-152.

Domonik A., 2003. Odwzorowanie powierzchni ciosowych piaskowców fliszu podhalańskiego w badaniach wytrzymałościowych z wybranych odsłonięć niecki podhalańskiej. Przegląd Geologiczny 51: 430-435.

Gołąb J., 1954. Flisz Podhala na zachód od Białego Dunajca. Archiwum Instytutu Geologicznego, Oddział Karpacki, Kraków.

Graniczny M., 1989. Fotolineamenty i ich znaczenie geologiczne. Instrukcje i metody badań geologicznych 50. Państwowy Instytut Geologiczny, Warszawa.

Halicki B., 1930. Dyluwialne zlodowacenie północnych stoków Tatr. Sprawozdania Państwowego Instytutu Geologicznego 5: 377-534.

Halicki B., 1963. Tektonika Podhala. Roczniki Polskiego Towarzystwa Geologicznego 33: 349-361.

Klimaszewski M., 1952. Rzeźba Podhala. Czasopismo Geograficzne 21-22: 237-250.

Klimaszewski M., 1988. Rzeźba Tatr polskich. PWN, Warszawa.

Kukulak J., 1988. Powiązania morfostrukturalne w rozwoju osuwisk zachodniego Podhala. Folia Geographica, Series Geographica-Physica 20: 33-49.

Kukulak J., 1991a. Stadia rozwoju rzeźby Doliny Domagalskiego Potoku na Podhalu. Rocznik Naukowo-Dydaktyczny WSP w Krakowie, Prace Geograficzne 13: 107-125.

Kukulak J., 1991b. Udział tektoniki w rozwoju poziomów grzbietowych Zachodniego Podhala. Folia Geographica, Series Geographica-Physica 22: 87-102.

Ludwiniak M., 2008. Ewolucja sieci spękań ciosowych we fliszu zachodniego Podhala. Przegląd Geologiczny 56(12): 1092-1099.

Maruszczak H., 1972. Wyżyny lubelsko-wołyńskie. W: M. Klimaszewski (red.), Geomorfologia Polski. 1. PWN, Warszawa: 340-383.
Mastella L., Ludwiniak M., Klimkiewicz D., 2012. Budowa geologiczna doliny Białego Dunajca. Przegląd Geologiczny 60: 496-505.

Mastella L., Mizerski W., 1977. Uwagi o budowie geologicznej SW części Podhala. Przegląd Geologiczny 10: 494-498.

Mastella L., Ozimkowski W., Szczęsny R., 1988. Tektonika północno-zachodniej części fliszu podhalańskiego. Przegląd Geologiczny 10: 566-571.

Morawski W., 1973. Gęstość ciosu w piaskowcach fliszowych wschodniego Podhala. Biuletyn Geologiczny Uniwersytetu Warszawskiego 15: 233-255.

Ostaficzuk S., 2003. Znaczenie wysokościowego numerycznego modelu terenu w kartografii geologicznej. Technika Poszukiwań Geologicznych, Geosynoptyka i Geotermia 224: 53-58.

Oszczypko N., 1966. Wpływ szczelinowatości na przepuszczalność warstw szaflarskich, Kwartalnik Geologiczny 10 (3): 820-831.

Ozimkowski W., 1992. Geologia fliszu podhalańskiego w ujęciu fotointerpretacyjnym. Biuletyn Geologiczny Uniwersytetu Warszawskiego 32: 93-118.

Pokorski J., 1965. Występowanie łupliwości we fliszu wschodniego Podhala. Kwartalnik Geologiczny 9: 616-623.

Romer E., 1929. Tatrzańska epoka lodowa. Prace Geograficzne XI: $1-186$.

Romer E., 1930. Zarys moich poglądów na tatrzańską epokę lodową. Czasopismo Geograficzne 8(1-2): 114-140.

Wasiluk R., 2009. Strefy tektoniczne południowo-zachodniego Podhala. Przegląd Geologiczny 57(1): 64-67.

Watycha L., 1976. Szczegółowa mapa geologiczna Polski 1:50 000. Ark. Czarny Dunajec (1048). Wydawnictwo Geologiczne, Warszawa.

Watycha L., 1977. Objaśnienia do szczegółowej mapy geologicznej Polski 1:50 000. Ark. Czarny Dunajec (1048). Wydawnictwo Geologiczne, Warszawa.

Zuchiewicz W., 1987. Ewolucja i strukturalne założenia sieci rzecznej Karpat w późnym neogenie i wczesnym czwartorzędzie. W: A. Jahn, S. Dyjor (red.), Problemy młodszego neogenu i eoplejstocenu w Polsce. Ossolineum, Wrocław: 211-225.

Zuchiewicz W., 2010. Neotektonika Karpat polskich i zapadliska przedkarpackiego. Wydawnictwa AGH, Kraków. 